\title{
Models for Education Worship in Early Childhood on Parenting Activities in Raudhatul Athfal Aisyah Az-Zahra
}

\author{
Masganti Sit ${ }^{1}$, Sholihah Titin Sumanti ${ }^{2}$, Juniawati Suza ${ }^{3}$ \\ 1,2,3 Islamic Education, Universitas Islam Negeri Sumatera Utara, Indonesia \\ Email: ulimurthado@gmail.com
}

\begin{abstract}
This study aims to determine the implementation of early childhood worship education in parenting activities in RA Aisyah Az-Zahra and develop steps to develop models of worship education in parenting activities. Although the focus of research is on RA Aisyah Az-Zahra. This research uses the Research and Development (RED) method. Mass product is the final product which is carried out by providing research results in the form of research reports in the form of journals and modules in the form of manuals and then disseminated by publishing journals and publishing modules. The product produced in this study is a parent guide module for early childhood worship education models.

Keywords: models; education worship; parenting activities
\end{abstract}

\section{Introduction}

The role of parents in delivering their children to be the generation of the Qur'ani is very necessary, this is because it is from parents that children first get religious education. Because educating and giving guidance is the best gift and the most beautiful jewelry given by parents to their children with a much better value than the world and its contents. (Rahman, 2005: 25). Educating children is not an easy thing, nor is work that can be done haphazardly let alone be a side job. For that parents must learn and know how to properly educate children as the teaching contained in the Qur'an and hadith.

The family is the first environment for every human being born into a world that is bound in marriage, interdependence, living together (one house) with a child (biological or adopted). As stated in Law number 52 of 2009 article 1 paragraph 6 which reads "Family is the smallest unit in society consisting of husband and wife, or husband and wife and children, or father and child, or mother and child". Parents will be the first to be a source of learning. Besides parents, individuals will learn from other individuals who live together in families such as brother and sister, this learning process is called informal education. (Sudirman, 2020)

Family education is very important. Various studies also show the same thing, including research by Irma et al. (2019: 223) at Masyitoh 1 Purworejo kindergarten which states that the involvement of parents in early childhood education needs to be built so that there is a reciprocal relationship between teachers and parents, parents need to increase awareness, a desire to learn together and participate participate in various programs formed by the school. Likewise, Genevi's research (2019) on the implementation of parenting programs for parents in growing child-friendly family behavior in Al-Ikhlas Bandung kindergarten stated that through the parenting program can foster child-friendly behavior for parents. Childfriendly family behavior can also be applied in everyday life such as: education-friendly, carefriendly, and others. 


\section{Review of Literatures}

Correct religious practices by parents will be an advantage for their children regarding their religion when they are adults. Conversely, the religion of a child is not good if during his childhood he was not well introduced to religion (Tiono, 2015:69). This role of parents really determines the level of religious diversity of children, parents are obliged to educate their children so that they always become our human beings who always carry out what Allah Almighty commands and keep His prohibitions away.

Worship education must be applied to early childhood even though it has not been charged to them, because the imposition of the law of worship comes into force at the age of baligh. Religious education must be taught to children from an early age, this was conveyed by Al-Maghribi that childhood is not a time of giving burdens of commands and prohibitions, but a time to instill values, training, nurturing, and education so that one day the child can arrive at the readiness stage to accept the burden of an order or prohibition at the age of baligh, so that he does not have difficulty in carrying out religious obligations and is ready when living life with confidence, confidence, and determination. (Al-Maghribi, 2019:177).

Ulwan (1995:153) emphasizes why children should be taught religion early on. The secret is, so that when the child opens his eyes and grows up, he has known the commandments of God, so that he hastens to carry it out, and understands His prohibitions, so as to avoid it. If the child has entered into the baligh period of understanding halal and haram laws, besides being bound by Sharia laws, then henceforth, he will only recognize Islamic law and law.

Hayati (2016:8) there are a number of ways to teach worship to young children including:

1. Explaining the virtues of fasting to them that this is because they enter heaven.

2. Accustoming them to fasting like fasting a few days in the month of shay'ban so as not to be surprised by fasting in the month of Ramadan.

3. Fasting during the day, and add time little by little.

4. Ending the meal until late in the night, it helps their fasting during the day.

5. Encouraging children to fast by giving prizes given every day or every week.

6. Flatter them in front of the family when breaking the fast and when dawn, it can raise the spirit of spirituality.

7. Encourage the spirit of competing to achieve good, if someone has many children without having to criticize.

8. Neglect hunger by sleeping or with games that do not require energy.

9. It is preferred that the father invites his child to pray at the mosque.

10.Visiting in the family home during the day and night whose children also fast to encourage children that not only he is fasting.

11. Reward children by cooking their favorite cake or buying their favorite food.

The parenting method for parents that is suitable for pre-school-age children especially for worship is as follows:

1. Exemplary Method.

Exemplary is an example that is followed by others and will be a role model in doing every action. (Mahmud, 2013: 151). Basically, humans are very inclined to require role models and role models who are able to direct humans to the path of truth that explains how to practice the Shari'a of Allah. 
2. Advice Method.

Advice is one method that is very important in educating and caring for children. Many things can be used by parents in giving advice to children.

3. Story Method.

Telling a story can evoke historical belief in children, in addition it can also add to the child's spirit and awaken a deep sense of Islam. Parents can tell Islamic stories as contained in the Koran and the stories of the Prophets of Allah.

4. Habituation Method.

According to Ulwan (1995:65) education by teaching and habituation is the strongest pillar in education and the most effective method in shaping children's faith and correcting their morals. The Habitual Method is the most effective method for families to educate early childhood worship. Educating children through habituation in Islam will realize community ties between the transfers from charity fardi (which is done alone) to the jama'i charity (which is done in touch) as it happens to prayer and fasting.

5. Method of Parable.

According to Muhammad Abduh, a parable is a phrase that is used to tell a certain event that is similar and the same as what is being experienced. (Bajuri, 2006:23).

6. The Targhib (promise) and Tarhib (threat) methods.

Human nature is a combination and a combination of good and bad. Al-Qur'an offers this effort in the methods of targhib (promise) and targhib (threat) therefore good deeds of children need to be rewarded and bad deeds. Before that happens there needs to be fencing. One thing that must be held by parents is balance and fairness in giving a balanced targhib and tarhib. Abu Yaqien argues that rewards or promises (targhib) and punishment or threats (tarhib) do not have to be material. (Yaqien, 1999: 10) Pat his shoulders and say, "You are great", rub his head, raise his thumb, and smile. But in the case of giving targhib or promises according to Amani Ar-Ramadi, it must be as soon as possible so that the child knows that all of that is the result of what he does (Ar-Ramadi, 2017: 179).

\section{Research Methods}

This research uses the research and development $(\mathrm{R} \& \mathrm{D})$ method. This research stage uses ten steps of research, namely: potential and problem steps consisting of literature study and field studies conducted by survey including literature study and field studies, data collection product design, design validation, design revisions, limited product trials, product revisions, wide-scale trials, product revisions, and mass products.

\section{Result and Discussion}

The feasibility of the product by linguists shows that the parent guidance module with an average yield of 4 (four) is considered good and valid, to be used as a parent guidance module in teaching early childhood worship in parenting activities. In the validation of linguists, there is no suggestion to revise because the module is considered to be good enough. As stated in the contents of the comments from the linguist validator that is, it is good enough as a module for early childhood.

The feasibility of the product by the material experts shows that the parent manual model of early childhood worship education is considered valid with an average score of 3.1. But at this stage it still needs to be improved again. As suggested by the experts, the improvement material includes: pictures on the module must be available, and parenting material must be added and adjusted to the module title. Suggestions and input from material experts used as researchers as an improvement to the parental guide module. After the module 
material has been revised, the researcher asks the material expert to give an assessment of the module that has been repaired. The revised assessment results are 3.8 in the valid category.

The feasibility of the product by graphic design experts shows that the parents' guide book for early childhood worship education models is considered valid with an average score of 3.2. This assessment is considered valid, but there are still things that have not met the provisions in making books to be corrected. After the revision of the parents' guide book on parenting models of early childhood worship education was assessed by graphic design experts and could be trialled, then the researcher then validated back to the graphic expert to request an assessment of the revised product which was 4.3. This shows that parental manuals are valid for the size of a book.

Furthermore, the steps for implementing the activities of parenting models of early childhood worship education include three steps namely:

1. Preparation.

In this preparation stage the researcher conducted the same perception with the parents of the students. These perceptions are carried out by researchers, among others, to: (a) agree on the number of participants participating in parenting activities, (b) prepare logistical activities, (c) prepare invitations for parenting participants, (d) prepare attendance list of parenting participants, (e) Prepare a parenting activity site.

2. Implementation.

The parenting activity is carried out with 5 (five) types of activities, namely: (a) the initial test activities include: post test distribution to participants and participants answering each question listed in the post test provided, (b) delivery of material consists of: Resource persons introduce self to participants of parenting activities, pray before the event begins, questions and answers related to the material and in accordance with the educational experience of worship taught by parents to their children at home, and presents material, (c) questions and answers include: If there are questions from participants in the activity, the resource persons answering questions according to the material presented, (d) playing a role. Parents can practice directly the dialog in the module in accordance with the illustrations depicted. Resource persons and parents can also choose and discuss the lessons learned about the roles that are put into practice in educating children, especially religious education, and (e) the final test is conducted at the close of the event, participants respond to the test provided by the speaker.

3. Evaluation.

Evaluation in this activity is carried out by giving tests to parents about the material both before giving the material and after delivering the material.

The limited field trial involved several participants, while the number of participants was only 5 parents for 5 days. Then after revising the results of the suggestions and input of the participants, then a wider field trial was conducted. The material presented in the limited field trials namely: teaching prayer, telling about the virtues of fasting, teaching zakat, teaching Hajj and Umrah, teaching fasting sunnah, teaching the importance of arafah days, gathering children when it comes to breaking their fast. At this stage the researcher conducted parenting activities and became a guest speaker as many as 4 meetings for 4 (four) material models of early childhood worship education. The material is: teaching prayer, teaching zakat, gathering children when it comes to breaking the fast, teaching Hajj and Umrah. Participants become resource persons to discuss 3 (three) materials, namely: telling about the virtues of fasting, teaching the fasting of the sunnah, explaining the importance of the day of Arafat 
After that, parents learn to be a resource person for 2 (two) meetings with one material in turn. As for the material presented, namely: Tells about the virtues of fasting and prohibition, Teaching Hajj and Umrah, Gathering children when breaking their fast. The average value of participants in the parenting activity in each of the early childhood worship education module materials is the score before using the module is 53.42 and the score after the use of the module is 79.71 .

Broader field test is an operational test conducted after the parents' guide book for early childhood worship education models is revised. This trial was conducted by involving more participants than participants on a limited trial scale. In a large-scale trial held at the same place namely RA. Aisyah Az-Zahra, but this time the participants consisted of 20 parents for 5 days. The material discussed in parenting activities are: teaching the shahada, teaching the call to prayer, teaching ablution, training children to fast, teaching alms, entertaining children when they are fasting, introducing zakat fitrah. Large scale trial used as an operational test at RA. Aisyah Az-Zahra got an average of 80 results.

The results of the evaluation of this study were carried out by comparing the scores before the researcher gave the parent guidebook module, and after the researcher gave the parent guidebook module to the participants of the prenting activities namely RA students' parents. Ayesha Az-Zahra. The results of this evaluation indicate differences in values before parenting activities are carried out and after parenting activities are carried out if before parenting activities get an average result of 54.42 then after parenting activities are carried out it gets better results than the previous results ie an average value of 85.57 . The product produced in this study is a module of the parent guide model of early childhood religious education. The material presented includes materials about worship. The feasibility test through expert testing, limited scale and broad scale field tests. Based on the overall results of the module product trials by experts and subjects to assess the feasibility of the modules developed. In the form of a parent's guide to teach worship education to children at home.

Parenting is really needed to increase parents' knowledge in terms of educating children, especially early childhood. Wise parents will have a profound influence on the development of their children. The behavior of a child is greatly influenced by parenting parents. Due to the lack of understanding of parents in providing good parenting will cause some irregularities in children's behavior (Ariyanti, 2016). To develop the nature of the child, the role of parents is very important in it. Parents must be able to provide materials that are relevant for their child's physical and physical development, be able to discover the talents of children, and explore the abilities of children and others (Purnama, 2016). Parents as educators from Allah must be able to carry out the mandate given to him. Giving aqidah inculcation, fostering morals, and practicing worship, as well as teaching prayers to children from an early age so that children will get used later as they get older will be a responsibility (Nazrah, 2018).

\section{Conclusion}

The conclusions of the study are: (1) Raudhatul Athfal Aisyah Az-Zahra has never held a Parenting activity let alone a Parenting model of early childhood education. This dive is in the RA school. Aisyah Az-Zahra only held a meeting of student guardians to discuss school issues related to annual activities, (2) The research was conducted at Raudhatul Athfal Aisyah Az-Zahra through a limited scale trial of only 5 (five) participants, namely parents of students. Then after the revision, it continues to a large-scale trial research. wide-scale trials bring more participants than ever, namely in large-scale trials, there are 20 parents who participated in 
parenting models of early childhood worship education, and (3) this study produced a product in the form of a parent guide module for religious education models early childhood.

Suggestions given are: (1) In order for early childhood education schools especially Raudhatul Athfal to pay more attention to early childhood worship education, (2) to school managers of Raudhatul Athfal in order to arrange a parenting program in schools to increase religious knowledge in parents, (3) for parents to read the parent's guide more often and put it into practice in their homes, and (4) for more students to do research on parenting related to children's religion from an early age.

\section{References}

Al-Maghribi. (2019).Begini Seharusnya Mendidik Anak, Jakarta: Darul Haq.

Ar-Ramadi. (2017). Amani, Menanamkan Iman Kepada Anak. Jakarta: Istabul.

Ganevi, Noni. (2019). Pelaksanaan Program Parenting Bagi Orangtua Dalam Menumbuhkan Perilaku Keluarga Ramah Anak (Studi Deskripsi di PAUD Al-Ikhlas Kota Bandung). Jurnal PAUD, Vol 1 no .

Hayati. (2016). Metode Melatih Anak Berpuasa Bagi Pemula, Jurnal PAUD, vol. 5 No. 1.

Irma, Cintya Nurika, et al.( 2015). Keterlibatan Orang tua dalam Pendidikan Anak Usia Dini di TK Masyitoh 1 Purwerejo, Jurnal PAUD, Vol.3. No.1

Kurniawan, Andree Tiono. (2015). Perkembangan Jiwa Agama Anak, Jurnal Elementary, Jurnal Humaniora, Vol 1no. 1.

Rahman, Jamaal Abdur. (2005). Tahapan Mendidik Anak Teladan Rasulullah, Bandung: Irysad Baitus Salam.

Rusydi Ananda. (2019). Desain Pembelajaran. Medan: LPPPI.

Ulwan, Abdullah Nashih. (1995) Pendidikan Anak Dalam Islam, Jakarta: Pustaka Amani.

Sudirman. (2020). The Efforts of Housewife to Improve Communication Patterns in the Family at Padang Lawas Regency, North Sumatera. Budapest International Research and Critics in Linguistics and Education (BirLE) Journal. P. 324-329. 